\title{
Contribution of traceability towards attaining sustainability in the textile sector

Vijay Kumar ${ }^{1,2,3,4 \dagger}$, Tarun Kumar Agrawal ${ }^{1,2,3,4^{*}+}$, Lichuan Wang ${ }^{1 *}$ and Yan Chen ${ }^{1}$

\begin{abstract}
Sustainability is a widely recognized concern and priority for healthy growth of the society and for preservation of the planet. Concerning this, textile sector has seen an unprecedented demand for sustainable products from the consumers, responding to which organizations have undertaken different initiatives. One of the major concerns in the textile sector is its complex supply chain networks and the involvement of numerous actors dealing with diverse raw materials and operations. The effective implementation of sustainability at the industrial scale would require the participation of all supply chain actors, along with an efficient traceability system to monitor and analyze different sustainability aspects. Furthermore, traceability is an integral part of the recycling process which contributes towards the sustainability. Therefore, the present article focuses on the contribution of traceable information towards attaining the sustainability in the textile sector. The three pillars of sustainability, namely, ecological, societal, and economic, are discussed for their relation and dependency on the traceability followed by an overview of the challenges in successful implementation of the traceability system, which is anticipated to shape the future research questions.
\end{abstract}

\section{Introduction}

Sustainability has been highlighted as a growing concern to the textile sector, given a fierce use of natural resources and exposure of penurious labor condition (Johansson and Månsson 2013). While natural fiber cultivation involving pesticides results in decreased soil fertility and water pollution, the textile industry is a prevalent contributor to serious health issues and environmental concerns including water and air pollutions (Strähle et al. 2015). The industrial processes consume huge amount of water and discharge pollutants, which significantly contribute the environment footprints (Pedersen and Andersen 2015). Additionally, the emergence of fast fashion has reduced the apparel life cycle, amplified the demand for clothing items, and increased the pressure on natural resources (Khurana and Ricchetti 2016; Steinberger et al. 2009). Subsequently, sustainability has become an important issue for the textile industry as well as for the consumers (Goswami 2014; Goworek 2011). Consumer demand for sustainable

\footnotetext{
* Correspondence: tarun-kumar.agrawal@ensait.fr; Icwang@suda.edu.cn ${ }^{\dagger}$ Equal contributors

${ }^{1}$ College of Textile and Clothing Engineering, Soochow University, 215021

Suzhou, China

Full list of author information is available at the end of the article
}

products has seen a steady increase along with their curious attitude for knowing sustainability practices in textile production and supply chains (Goswami 2014). Besides this, many non-profit organizations have indulged in name and shame campaigns which identify the malpractices carried out by the brand or their suppliers and then publicly calling their names, thus, severely affecting the brand image. Due to this, organizations are becoming more concerned to sustainability aspect in their business practices and conveying this information to the consumer. More and more companies are using corporate social responsibility (CSR) reports illustrating their efforts for sustainability (Kozlowski et al. 2012). In addition, from the marketing perspective, sustainability acts as a tool to create a competitive edge by highlighting the sustainability practices.

Sustainability or sustainable development is defined as "Economic and social development that meets the needs of the current generation without undermining the ability of future generations to meet their own needs" (World Commission on Environment and Development 1987). This definition combines economic, social, and ecological aspects together under the umbrella of sustainability and has been widely used in the literature. The retail brands 
use different techniques to convey the sustainability information to consumers in various forms, which include certification from third party, special logos, and traceability information (Henninger 2015). A lot of research in the past has been focused to attain sustainable supply chain network from technical and organizational aspects (Chi 2011; Cucchiella et al. 2012; De Brito et al. 2008; Nagurney and Yu 2012; Seuring and Müller 2008).From the technical aspect, certifications and indices designate the product in a certain category such as organic or fair production practice while a detailed information of sustainability practices or influencing factors go missing (Goswami 2014). Concerning this, traceability has emerged as a feasible solution which can not only be used to indicate the environmental sustainability aspect of the product but also other customer-concerned tangible and intangible product characteristics such as source of individual raw material used in production, history of individual component, and product footprints in the supply chain can be conveyed to the end-users (Agrawal et al. 2016; Goswami 2014; Guercini and Runfola 2009; Henninger 2015; Kumar et al. 2016). Furthermore, traceability acts as a valuable mean to verify the product related sustainability claims, thus helping companies to advance their sustainability goals (A report by UN Global Compact Office 2014). To make accountable claims such as product life cycle impact or social impact, it is imperative that all product aspects including production history, raw materials information, logistics data, etc. are properly recorded and are verifiable. In this context, traceability is irrefutably required in the industry, which connects various supply chain stakeholders and facilitates the information exchange pertaining to the product. Additionally, government regulations have mandated the traceability in some sectors of textile to implement traceable sourcing information about the supplies (Alves et al. 2013). In this direction, the aim of this conceptual paper is to comprehensively investigate the contribution of traceability towards attaining sustainability in the textile sector. Here, the discussion is made based upon the literature review of scientific and non-scientific literature which was related to traceability and sustainability in textile sector.

\section{Definitions of sustainability and sustainable development}

The idea of sustainability was first issued at the global level by the International Union for the Conservation of Natural Resources in 1980, which proposed sustainability as industrial and economic growth without hampering the environment (Kutay and Tektüdekci 2016). Over the decades, it has become a great concern and widely recognized by various business leaders, government and non- government organizations of all kinds. In this direction, the term sustainable development has been popularized after it appeared in a report widely known as Brundthland Report in 1987 (World Commission on Environment and Development 1987). While sustainability can be comprehended as a state of balance between social, economic, and environmental health of a community or nation or the earth; sustainable development is a process to attain the sustainability (World Commission on Environment and Development 1987). Therefore, sustainable development is not a state, rather a procedure that leads to the sustainability. Sustainability has been a widely discussed in the literature and delivered hundreds of definitions (Jacobs 1995), which integrate its different facets. The followings enlist some of the definitions related to sustainability and sustainable development proposed in the literature,

"Sustainable development is development that meets the needs of the present without compromising the ability of future generations to meet their own needs" (United Nations General Assembly 1987) "The concept of sustainable development provides a framework for the integration of environment policies and development strategies" (United Nations General Assembly 1987)

"...long-term continuous development of the society aimed at satisfaction of humanity's need at present and in the future via rational usage and replenishment of natural resources, preserving the Earth for future generations" Agenda21 (1992).

"The overall goal of sustainable development is the long-term stability of the economy and environment; this is only achievable through the integration and acknowledgement of economic, environmental, and social concerns throughout the decision making process" (Emas 2015)

\section{Understanding the textile sector from sustainability and traceability perspective}

Textile industry is one of the jobs creating industries in the less economically developed countries. In the year 2000, the textile industry had employed 25.6 million people and contributed nearly $6 \%$ world production among all manufacturing sectors globally (Allwood et al. 2006). Textile production generally requires a semiskilled workforce; therefore, it opens high employment opportunities for developing countries with a large unskilled workforce and helps in social development. For example, Nicita and Razzaz (2003, p. 5) reported an expected average improvement of $24 \%$ in purchasing power of individuals employed in T\&C sector in Madagascar. Low wages and relaxed environmental conditions have further encouraged enterprises to move towards the developing countries, which contribute to 
lowering the product cost. Moreover, due to comparatively low capital investments and high employability, textile industry directly or indirectly contributes towards the social development of many low-income countries.

From the sustainability perspective, the textile industry is a highly criticized sector. It is regarded as one of the highly polluting, resource consuming and labor intensive industries (De Brito et al. 2008). Due to involvement of numerous stakeholders-including different suppliers, fiber producers, yarn manufacturers, weavers, chemical processors, apparel industries, retailers, logistics and distributor partners, post-consumer actors, and service providers-it is a complicated sector where supply chain actors do not always act with good intention towards sustainability (Shih and Agrafiotis 2015). On the other hand, the textile production processes intensively use chemicals and water, which generate a high environmental impact. The chemical compounds such as dyes are not completely utilized and get washed away with the effluents (Islam and Khan 2014). The non-biodegradable and carcinogenic components of these chemicals directly contaminate the nearby water resources and affect the locality severely (Hessel et al. 2007). Further, the recently emerged concept of fast fashion has reduced the cloth and fashion lifecycle, thus, amplified the textile demand. The fiber consumption has almost doubled in mere 20 years, i.e., from 1990 to 2010 (Khurana and Ricchetti 2016). From the raw material perspective, cotton-accounts for the largest portion of natural fibers consumptioninvolves the consumption of a high amount of water, insecticides, and pesticides and uses a significant portion of cultivable land (Hessel et al. 2007). Further, with growing competition and push for low-cost product, the textile and fashion sector is in limelight for various unethical practices such as use of transgenic cotton, poor environment and working condition, unethical sourcing and manufacturing. Nevertheless, a strong movement has gained pace forcing the organizations to find socially acceptable and eco-friendly solutions while fulfilling their economic expectations (Wigley et al. 2012).

Due to growing concerns from governments and consumers, sustainability has emerged as a key issue for all the textile industries (Kozlowski et al. 2012; Strähle et al. 2015). Profound researches have been undertaken in the last decade to achieve a balance between sustainability and business needs. Besides, sustainability has also emerged as an important marketing tool, genuinely used to uplift the brand's image and identity. De Brito et al. (2008) described sustainability "as a springboard to reach environmental and socially conscious customers". Organic fiber labels, green certifications, traceability numbers, etc. are few examples which are widely used to convey sustainability aspect of raw materials or final products to other supply chain members or the end-users (Henninger 2015). However, most of the above initiatives are incomplete or inappropriate without transparency in the supply chain.

From a customer perspective, sustainability is an informational aspect of the product which describes the product's relation with the basic components of sustainability, namely, ecological, societal, and economic. Organic cotton, green chemistry-based processes, and the use of clean energy sources contribute towards the ecological perspective while fair trade in cotton production, textile manufacturing, etc. contribute to the societal and economic perspectives. In the textile supply chain, brand owners act as resellers and production activities are outsourced to subcontractors or suppliers which carry the main production activities and selection of raw materials and chemicals (Lam and Postle 2006). Therefore, the sustainability aspect is largely defined by these suppliers and subcontractors working together to attain the sustainability goal (Germani et al. 2015). However, as the brand owners cannot verify all sustainability claims by lab-based experimental (such as the verification of organic cotton (Bureau Veritas2010)), it is important that they gather all product related traceability information to make a claim. Similarly, the societal and economic aspects need product information systematically retained to validate the claim (Johansson and Månsson 2013). Hence, the relevant traceability information acts as an integral part of sustainability and subsequently, the product-related data needed to deliver to make accountable claim pertaining to the sustainability (Johansson and Månsson 2013).

As aforementioned, textile sector is long criticized for sustainability. Big fashion brands are being consistently exposed for unsustainable practices including child labor, use of fake organic cotton, marginal salary of workers to name a few (Seuring and Müller 2008). Despite the long-standing concern, according to Khurana and Ricchetti (2016), the sustainability awareness in textile sector is still in "statu nascenti". Sustainability without the traceable information can be attributed as mere "green washing" which can be used as a marketing tool to gain customers attention, but the real impact remains unknown. For instance, a well known fashion brand has been accused of using child labor in the farming of organic cotton (Phelan 2011), which is partly sustainable from the ecological perspective if compared with the conventional cotton, but the involvement of child labor makes it contrary. The statu nascenti state of sustainability can be further related to the traceability practice in the sector. Nimbalker et al. (2015) reported 59 fashion brands for the traceability information pertaining to their suppliers. The results stated by Nimbalker et al. (2015) in their report show that around 15\% brands did not even identify their first tier suppliers and condition is worse when only less than $10 \%$ of the brands were 
having 100\% information about raw material suppliers, while remaining $90 \%$ percent know partially or have no information at all.

In the state of such opaque supply chains, it is very challenging to make sustainability claims. According to Zhang and Kraisintu (2011), traceability is considered as an integral component for sustainable supply chain. Further, product recycling is a contemporary practice for sustainability. According to McDonough and Braungart (2010), recycling or giving back to the planet is one of the key necessity prerequisites for a healthier and sustainable future. Products should be designed in a way that they can provide nourishment for something new at the end of their life, i.e., emphasis should be given cradle to cradle instead of cradle to grave (McDonough and Braungart 2010). However, correct information about the product's components plays a crucial role so that disposed products can be segregated for using appropriate techniques or operations to pursue the cradle to cradle concept. In this context, global recycle standards mandate traceability as a pre-requisite to sort the product before the recycling process so as to prevent the mixing of different materials (Global Recycle Standard 2011).

It is worth mentioning that sustainability is independent of traceability, but in order to make an accountable claim, traceability is inseparable from sustainability and it acts as a foundation for the three previously mentioned elements or pillars of sustainability. The next section substantiates the role of traceability in supporting sustainability.

\section{Contribution of traceability to the sustainability}

International organization for standardization (2007) defines traceability as the "ability to verify the history, location, or application of an item by means of documented recorded identification". Traceability, as the name specifies, is a link that connects various element of information pertaining to a product (Agrawal et al. 2016). The basic notion of traceability can be seen as informationally extending the boundaries of the stakeholders in the supply chain beyond their organizational scope. As the textile sector is a fragmented sector-comprising of various suppliers, manufacturers, and other stakeholders-the sustainability cannot be attained by the isolated efforts of an actor, rather it is a cohesive involvement of all. In this context, traceability integrates the whole sector informationally. It harmoniously and equally supports each pillar, adding to their strength and fundamentals to achieve the objectives of sustainability. The following subsections describe the contribution of traceability towards each pillar of sustainability:

\section{Ecological pillar}

The ecological pillar is probably the most distinguished component of sustainability. This can be linked to the study conducted by Gilg et al. (2005) which identifies the variables including environmental and social, sociodemographic, and psychological factors affecting the consumer purchase behavior for green products. However, it was postulated in the same study that the products with more perceived environmental friendly aspect will be more purchased by the consumers who prefer green products (Gilg et al. 2005). The textile sector is a customer-driven sector, where the customers' demands shape the organization strategies. In this context, the attention from consumers for environmentally friendly product acts as a catalyst for the sustainable apparels (Wigley et al. 2012). The eco-labels are widely used to provide such ecological information about the product. Despite ecological evidence they provide, eco-labels have been criticized for being complex to provide useful ecological information and creating confusion leading to greenwashing (Henninger 2015). More than 100 different eco-labels have been established for the textile sector, and consumers find it challenging to identify the environmentally friendly products due to a large number of variants. Thus, experts believe that eco-labels do not necessary contribute to promote eco-friendly products to the consumers (Henninger 2015).

The ecological aspect of a textile product can be divided into three categories, namely, raw materials and manufacturing phase, use phase, and post-use phase. The first category depends on the used raw materials, chemicals, the extent of water consumption, energy resources depletion (electricity or other fuels used), etc. during the sourcing and manufacturing phase. The second category includes the energy used during the use phase such as washing, drying, and ironing, whereas the last category includes the impacts originating from the product disposal including recycling and incineration. Subsequently, the complete ecological information is difficult to communicate using an eco-label. In this context, traceability is a tool that can potentially help in communicating product related information and thus it can create more trust since the information can be traced back to the original source (Corbellini et al. 2006; Henninger 2015). Moreover, the ecological aspect of a product varies based upon the manufacturing and use location (Yasin, Behary, Rovero et al. 2016). Source of energy varies from place to place, some countries generate electricity from coal while some others use nuclear sources for the same; subsequently, they have different environmenal impacts. Therefore, the eco-labels do not actually represent the global ecological aspect; rather they are restricted to one or few aspects thus limiting the holistic understanding of real sustainability.

Traceability is a tool which can change the landscape of perception of apparels' environmental footprint. For instance, life-cycle assessment (LCA) is a widely 
used technique to calculate the footprint of a product, which can act as an ecological sustainability indicator (Kozlowski et al. 2012). This essentially relies on traceability information about the product, processes, and location. For example, from process perspective, the dying process uses water as low as $15 \mathrm{M}^{3} / \mathrm{t}$ in cold pad-batch dyeing to as high as $290 \mathrm{M}^{3} / \mathrm{t}$ in the paddly dying process (Ren 2000). Similar example can be seen from the location aspect as $1 \mathrm{~kg}$ of polyester production consumes $127 \mathrm{MJ}$ of energy in America in comparison to that of $104 \mathrm{MJ}$ in Europe (Cherrett et al. 2005) and, $109 \mathrm{MJ}$ in the UK (Collins and Aumônier 2002). Thus, the information about the processes and production location can largely change the ecological footprint of a textile (Muthu et al. 2011). Moreover, LCA literature shows that a large proportion of the energy consumption can expected during the use phase of a product (Muthu 2015). For example, cotton fiber-based apparels consumes $>70 \%$ of total energy during the use-phase-which could significantly vary based upon the country or place, or the use behavior (Yasin, Behary, Rovero, et al. 2016). Similarly, the textile disposal impact can differ based upon the waste management strategy (Yasin, Behary, Curti, et al. 2016). Therefore, ecological sustainability of a textile product is not limited to sourcing and manufacturing phase and can be largely affected by the post-sale phase where traceability information can assist the consumer to perceive, evaluate, and reduce the environmental impact, hence, it can contribute towards sustainability. In fact, multiple brands have identified traceability as a competitive factor and have taken initiatives to provide detailed traceability information to the consumers. For instance, Rapanui Clothing (2016) provides full traceability information related to manufacturing, energy use, carbon footprint, and how the end-users can reduce the carbon footprints during use-phase of the products. Similarly, the project Clothing Traceability is such a venture which aims to connect various textile supply chain actors-from fiber to finished garment-to generate a deeper understanding of the clothing life-cycle impact (Clothing Traceability 2017).

\section{Societal pillar}

While ecological aspect of sustainability is highly recognized by the consumers, societal aspect is the main grassroots of issues that have recently criticized in an extensive manner. Interestingly it is not a new phenomenon. Incidents concerning lack of social responsibility have been criticized over the decades (Hethorn and Ulasewicz 2008). However, it is difficult to conclude if a significant improvement has been observed. Every time, analogous clarifications of inadequate sustainable supply chain management have been made over the decades by different brands (Khurana and Ricchetti 2016).

The fundamental foundation of the societal problem lies in the structure and opaque supply network of the textile sector. The retailers are often facing a high level of competition which forces them to provide the better quality products at a lower price (Shih and Agrafiotis 2015). The retailer or brand owner acts as "supply chain-captain" driving the whole sector (Lam and Postle 2006) and initiates the demand/order for the upstream suppliers; hence, establishes an upper hand in the multiple-actor supply-network. Retailers with big ordersize are able to enforce their terms, including limited profit sharing, on the upstream actors who conversely prefer to set a long-term relationship with the brand for consistent demand (Lam and Postle 2006). Additionally, a retailer acts as "gate-keeper" between the industry and the consumers and the textile products are recognized by the retailer/brand name. The retailers have opportunity to outsource production activities to offshore suppliers of destinations where cheap labor, easy availability of resources, and favorable government regulations can assure the cost reduction and hassle-free production (Shih and Agrafiotis 2015). Since the retailer cannot directly supervise (or sometimes opportunistically ignores) the distantly located suppliers, this creates a malicious opportunity for the latter, including the marginal salary of the workers to reduce the production cost. It has been observed in the past that some textile suppliers associated with big brands obtained their quality and standard certifications by bribery or illegal means and were involved in unsustainable practices including marginal salary of the workers, child labor, etc. (Cline 2012; Martin 2013; Rose 2014). For example, a textile mill in Pakistan had obtained the SA8000 certification for health and safety a week before the same mill confronted a deadly fire in 2012 leading to the multiple deaths (Walsh and Greenhouse 2012). A similar incident happened in Bangladesh-also known as Rana Plaza incident-where a multi-story building collapsed due to poor infrastructure and illegal construction of factory floors, leading to death of more than a thousand people (Burke 2014). Additionally, chances are higher for these illegal practices when some suppliers further commission their production activities to uncertified subcontractors, without informing the brand owners (Cline 2012; Martin 2013). As a result of such incidents, brands have intermittently faced campaigns initiated by the consumers and nongovernment organizations to uncover their suppliers' details for the social transparency of the supply chains.

Owing the complexity of the textile supply networks, it is indeed a challenging task for the brands to recall all the suppliers and to monitor their activities. In this 
context, traceability has emerged a practical solution to create social transparency. Traceability, by definition, is the "ability to verify the history, location, or application of an item by means of documented recorded identification" (International organization for standardization 2007); therefore, it allows recalling of the product information. The traceability number used is to uniquely identify the product, and the product-linked information is thus can be retrieved for each product using the unique traceability number. The traceability information allows each of the supply chain actors identify thus improving transparency in the supply chain. A number of initiatives have been witnessed in the past in this direction. For instance, All American Clothing Co. provides a traceability number with their jeans which allow consumers to trace the history of the jeans back to the cotton field (Goswami 2014), which alternately allows the customers to decide the sustainability aspect of the garment. Similarly, Nudie Jeans Co. has implemented a high level of traceability in its supply chain and disclosed the name of suppliers on its website to create more transparency in the supply chain (Egels-Zandén et al. 2015).

As the textile industry has migrated towards some Asian countries, the western countries have seen an adverse social impact on the jobs due to this migration. The employment in textile, clothing, and leather sector has shrunk by $37 \%$ in a decade, i.e., 2003-2013 decade and expected to further decrease by $13 \%$ in $2013-2025$ -which is a great social and economic concern to the west. This is primarily attributed to the fierce competition offered by the Asian countries (Panorama 2014). In this context, a number of researchers (Goswami 2014; Guercini and Runfola 2009) have argued about the potential of traceability information that could help the local manufacturing to sustain and subsequently contribute to the social sustainability. Goswami (2014) further established that customers have a growing interest in fiber origin. The information on "made-in" label is mostly limited to a place where the fabric is assembled while it hides the other important product aspects including the fiber origin and mediators. Therefore, exposing the information about cotton growing could help local cultivator since people can observe the farming practices of local cultivator for transparency. Guercini and Runfola (2009) further argued that apparel "madein" is an important aspect for the local brands to create a competitive edge. Therefore, the traceability information which provides each aspect of the apparel product could help the local brands to compete in the global competition and hence contribute to the social sustainability.

Furthermore, consumer health and security are important and obligatory requirements for societal sustainability which are supported by a good traceability.
For instance, textile and fashion product category is among top product categories contributing to high number of notified cases for product recalls in the European Union member states controlled by the RAPEX (Rapid alert system for dangerous non-food products) (Kumar and Ekwall 2016). These recalled products are generally non-compliant to the safety standards; therefore, they are potentially dangerous for the end-users. Although product recall can be regarded as a positive action, contributing to the removal of harmful products, the main issue arises in the recall execution as product identification and distribution is a complex task in the market. Textile products generally have similar characteristics, and it is difficult to identify them based on the vague specifications such as color or design. Furthermore, it is important that the surveillance authorities have relevant information of product distribution in the market so that recalled products can be efficiently tracked. In this context, experts propose using traceability system which maintains the data of product flow in the market (Directorate General Health and Consumers 2013). Moreover, as traceability works on the identification of products uniquely using labels including RFID tags, QRand bar-codes, and printed labels, this helps in avoiding vague identification features, and the information encoded on the traceability labels contributes to product identification and organizing the product recall. In fact, traceability is a well-established tool in the food sector to ensure that all food items can be tracked throughout the supply chain to provide safe products to the consumers and to organize a targeted withdrawal (or recall) of food items which are identified as contaminated or not complying with permitted standards (Dabbene et al. 2014; Regattieri et al. 2007).

\section{Economic pillar}

Economic pillar is an essential support for a sustainable and durable system. Harwood (1990) describes the economic sustainability as "a system that can endlessly develop towards greater benefit for people, greater efficiency of resource use, and balance with the environment that is friendly to people and other species". Economic sustainability is particularly required in fierce global competition. Furthermore, many actors in textile supply chain are the small-scale industries where financial viability is particularly relevant for continuous functioning. In this context, a substantial research in the past has explored the contribution of traceability in the economic sustainability of the organization or supply chain.

Zhang and Kraisintu (2011) describe the contribution of traceability in negative and positive perspectives related to the economic sustainability. While positive aspect relates to the direct economic gains, the 
implementation cost relates to negative perspective of the traceability. Further, traceability information can be related to two key economic factors namely cost and benefits. Cost signifies to the expenses that a buyer or the retailer bears in case of external quality failure. Benefit implies the additional economic incentives that the traceability adoption offers to an organization. Traceability particularly benefits the enterprises with information beyond their organizational scope which aids them with the better control and understanding of the supply chain. This includes the benefits associated with better inventory management, reduced stock levels, better demand-production balance, and more visibility of supplies in the supply chain (Alves et al. 2013; Gobbi and Massa 2015; Guercini and Runfola 2009; Kwok and Wu 2009). Products can be efficiently located and tracked using traceability information inside the supply chain, which improves the actors' responsiveness, reduces the production lead-time, and contributes towards the abovementioned benefits (Kwok and Wu 2009). Further, traceability supplies the visibility of the supply chain to the end-consumer. It improves the customers' confidence while buying the product, which helps the brands in the long term by building the brand identity for transparency perspective. Interestingly, some customers consider traceability equivalent to certification (Ubilava and Foster 2009), which can potentially add to the abovementioned retailer-end-user relation. Furthermore, as aforementioned product recall is a well-recognized issue. In this context, traceability can help the identification of recalled product more precisely thus efficiently implement the removal of recalled products from the market. Subsequently, this can help the organization from the bad reputation originated from the product recalls (Zhang and Kraisintu 2011).

One important area that concerns the textile sector is the counterfeiting; which is a big threat for social and economic sustainability. European Commission border customs forces have seized $\sim 1.3$ million ready to wear clothing articles, which account for more than $€ 48$ million in 2014 (European Commission 2015). Similarly, US homeland security reports the contribution of wearing apparels/accessories is more than $\$ 113$ million in year 2014, which is $9 \%$ by value of total counterfeit seizure (US Department of Homeland Security 2015). While counterfeit affects the brands in terms of revenue loss, brand reputation is another aspect which affects them in the long term. Besides the final product, the counterfeit is also related to materials used in the intermediate manufacturing process; thus, complicating the identification or controlling of the counterfeit products (Corbellini et al. 2006). In this context, a stream of researchers and experts have identified the role of traceability in product authentication which can help the end users to differentiate among genuine and counterfeit products. (Agrawal et al. 2016; Corbellini et al. 2006; Directorate General Health and Consumers 2013; Kumar et al. 2016).

\section{Challenges in implementing traceability assisted sustainability}

Transparency is the fundamental requirement for sustainability, and in this direction traceability assists in integrating different stakeholders in the supply chain to create transparency along with supporting different aspects of the sustainability. However, implementing traceability is a challenging task owing to the organizational and technological complexities associated with the textile sector and expected outcomes. The organizational complexities can be analyzed from the organizational and supply chain context of the sector. The textile sector is a dispersed network of actors carrying different operations (Shih and Agrafiotis 2015). Despite having dominance in the supply chain, all the upstream suppliers are not managed by the retailer/brand owner. The brand owners monitor only those suppliers which affect them mostly. The rest of the links are either monitored indirectly (such as random audits or certifications) or not monitored at all. Hence, the textile supply chain is not an integrated sector, and the retailer-which acts as supply chain captain-partially controls the supply chain, and there is no single actor which can enforce the strategies for traceability (or transparency) throughout the supply chain. Additionally traceability is a double-edged sword, it brings better control and other benefits which assist transparency in the supply chain, however, the increased transparency is not always beneficial and acceptable to all. For example, the supply chain actors would not like to disclose all his suppliers and related information because this may benefit the opponents directly or indirectly and affect their strategies. Moreover, there is often an involvement of agents (or middlemen) between the buyers and the suppliers, and the names of suppliers act as a competitive factor for the agents. As agents disclosing the name of suppliers for supply chain transparency can potentially lead the buyers to bypass the agents for future contracts with the suppliers; therefore, it is not considered a favorable option to the agents (Egels-Zandén et al. 2015).

As the consumers hold the brands responsible for the supply chains, the brand owners need to monitor all the suppliers to ensure that traceability information is correct to avoid any public scrutiny, which is undeniably time-consuming and monetarily expensive. Other larger issue concerns the traceability is unavailability of global regulations. Some countries have local regulations for traceability such as EU has regulations which mandate the traceability for the entire chemical used in the 
textile industry (Alves et al. 2013); however, this kind of regulation is limited to a specific geographic space whereas present textile supply chains are globally spread.

Technological aspect includes the challenges associated with the technical establishment of a supply chainwide traceability systems. Sustainability is an integrated phenomenon where all the stakeholders in the production, consumption, and disposal phases contribute towards the sustainable practice (Kozlowski et al. 2012), and a traceability system would be required which can integrate all of them. In this context, a common framework and standardized semantics would be needed. Further, the actors in the supply chain would need to comply with a common information exchanging semantics for a streamline exchange of traceability information. It can be also noted that the retailers are expected to be the top beneficiary of the traceability as the consumer identify the whole supply chain with the brand identity, whereas traceability implementation would require investment from all upstream suppliers. Some of the supply chain actors are small-scale industries for whom the financial investment on traceability might not be a lucrative option especially when the profit margin is small and the return is expected in the long term. Furthermore, the traceability is an informational aspect which is managed by and works on the credibility of the traceability information holder or owner; consequently, there is a large room for the owner to fabricate the sustainability information, who can falsely manufacture the sustainability aspect. Also, the sustainability is not limited to manufacturing or industrial processing, but also defined by the use and disposal, and for this, the traceability information should be delivered to the endusers and disposal handlers, which requires information mapping to each product individually. Barcodes, RFIDs, and other traceability number-based labels are used to uniquely identify the products in the supply chain, and the traceability information is delivered to the end-user with reference to these labels. Although the price of an RFID less than a dollar, it is still very high particularly for low-priced garments, which is a challenge in implementing RFIDs in the supply chain (Nayak et al. 2015). Moreover, as RFID tags integrated in the product for traceability can be used for unsolicited tracking of the end-users, which creates privacy concerns. In fact, the cloth retailer Benetton had to plan the withdrawal of the use of RFIDs in their products because of these probable privacy concerns (Juels 2004; Nayak et al. 2015). Furthermore, the printed labels including QR- and barcodes are easy to replicate to use with the counterfeit products. To implement a communication in the traceability information from manufacturing until disposal of the product, the economical traceability markers need to be devised which can recall the product information at all stages of the product lifecycle.

\section{Conclusions}

Sustainability and transparency are growing concerns in the textile sector, given its impact on environment and society particularly resulting from a fierce competition of the organizations to achieve economic growth. Sustainability is a multifaceted concept combining the economic, social, and ecological aspects a product starting from cradle to grave. In this direction, various sustainability initiatives have been pursued by different textile brands such as introducing sustainability into corporate social responsibility, green/compliance certification, and designing of products according to cradle to cradle concept. Concerning this, traceability is one such initiative which has been regarded as vital component for pursuing the different aspect of sustainability. The present paper, in this direction, provides a comprehensive analysis on how traceability can be used to progress sustainability goals and the potential challenges in real implementation of traceability assisted sustainability. Textile sector is a distributed and heterogeneous sector combining different actors dealing with a wide range of raw materials and distinct processes. Traceability, in such complex supply network, extends the informational boundaries of the stakeholders beyond their organizational scope which helps in informationally integrating the whole supply chain. This integration brings more visibility, transparency, and accountability in the supply chain thus supports the sustainability claims. In fact sustainability is based upon the parameters many of which are informationbased and cannot be verified or claimed by the lab-based cross examination of the product; rather they are based on a proper information management for the claim and verification. Particularly to the information-based aspects, traceability acts a fundamental requirement-which retains the links between various components of information such that various sustainability claims can be verified (Schröder 2008); therefore, it provides the ability to trace back the product history and then authenticate the claims. Furthermore, traceability acts as a vital component in post-sale and post-use phases which provides crucial information to reduce the impact of product. Since this paper is a literature review-based conceptual paper which provides a holistic perspective, further research, both empirical and non-empirical aspects must be done in order to substantiate the best traceability practices such as identification of critical component of traceability information and supporting technologies, for pursuing the sustainability goals. Furthermore, from the organizational point of view, future research can be focused on how traceability can be implemented in a supply chain network without jeopardizing or minimally impacting the relation. 


\section{Acknowledgements}

This work is comprehended in the framework of Sustainable Management and Design for Textiles (SMDTex) PhD Programme, which is funded by the European Commission.

\section{Authors' contributions}

VK and TKA are equally contributing authors, where both have collected and analyzed literature, and written the manuscript. LW and $Y C$ contributed in a part of literature analysis and refinement of the manuscript. All authors read and approved the manuscript.

\section{Competing interests}

The authors declare that they have no competing interests.

\section{Publisher's Note}

Springer Nature remains neutral with regard to jurisdictional claims in published maps and institutional affiliations.

\section{Author details}

${ }^{1}$ College of Textile and Clothing Engineering, Soochow University, 215021 Suzhou, China. ${ }^{2}$ University of Borås, Borås, Sweden. ${ }^{3}$ ENSAIT/GEMTEX, Roubaix, France. ${ }^{4}$ Universite Lille1-Sciences and Technologies, Lille, France.

\section{Received: 13 December 2016 Accepted: 20 April 2017}

Published online: 19 May 2017

\section{References}

A report by UN Global Compact Office. (2014). A guide to traceability: a practical approach to advance sustainability in global supply chains.

Agenda21. (1992). United Nations Conference on Environment \& Development. United Nations Department of Economic and Social Affairs. Rio de Janerio, Brazil: United Nations.

Agrawal, T. K., Koehl, L., \& Campagne, C. (2016). Cryptographic tracking tags for traceability in textiles and clothing supply chain. In X. Zeng, J. Lu, E. E. Kerre L. Martinez \& L. Koehl (Eds.), Uncertainty Modelling in Knowledge Engineering and Decision Making: Proceedings of the 12th International FLINS Conference (pp. 800-805). Singapore: World Scientific.

Allwood, J. M., Laursen, S. E., de Rodriguez, C. M., \& Bocken, N. (2006). Well dressed? The present and future sustainability of clothing and textiles in the United Kingdom. Technical annex. Institute for Manufacturing, University of Cambridge. http://www.ifm.eng.cam.ac.uk/uploads/News/technical_annex_ 201106.pdf. Accessed 10 Dec 2014.

Alves, B., Schumacher, M., Cretton, F., Le Calvé, A., Cherix, G., Werlen, D., et al. (2013). Fairtrace: applying semantic web tools and techniques to the textile traceability. In S. Hammoudi, J. Cordeiro, L. Maciaszek, J. Filipe (Eds.), Enterprise Information Systems. ICEIS 2013. Lecture Notes in Business Information Processing, 190(pp 68-84). Switzerland: Springer, Cham.

Burke, J. (2014). Rana Plaza: one year on from the Bangladesh factory disaster. TheGuardian. https://www.theguardian.com/world/2014/apr/19/rana-plazabangladesh-one-year-on. Accessed 4 Dec 2016.

Cherrett, N., Barrett, J., Clemett, A., Chadwick, M., \& Chadwick, M. J. (2005). Ecological footprint and water analysis of cotton, hemp and polyester. Sweden: Stockholm Environmental Institute.

Chi, T. (2011). Building a sustainable supply chain: an analysis of corporate social responsibility (CSR) practices in the Chinese textile and apparel industry. Journal of the Textile Institute, 102(10), 837-848.

Cline, E. L. (2012). Overdressed: the shockingly high cost of cheap fashion. New York: Portfolio/Penguin Group.

Collins, M., \& Aumônier, S. (2002). Streamlined life cycle assessment of two Marks \& Spencer plc apparel products. Oxford: Environmental Resources Management.

Corbellini, S., Ferraris, F., \& Parvis, M. (2006). A cryptographic system for brand authentication and material traceability in the textile industry. In 2006 IEEE Instrumentation and Measurement Technology Conference Proceedings (pp. 1331-1335). IEEE. Accessed 23 November 2016

Cucchiella, F., Koh, L., Walker, H., \& Jones, N. (2012). Sustainable supply chain management across the UK private sector. Supply Chain Management: An International Journal, 17(1), 15-28.

Dabbene, F., Gay, P., \& Tortia, C. (2014). Traceability issues in food supply chain management: a review. Biosystems Engineering, 120, 65-80.
De Brito, M. P., Carbone, V., \& Blanquart, C. M. (2008). Towards a sustainable fashion retail supply chain in Europe: organisation and performance. International Journal of Production Economics, 114(2), 534-553.

Egels-Zandén, N., Hulthén, K., \& Wulff, G. (2015). Trade-offs in supply chain transparency: the case of Nudie Jeans Co. Journal of Cleaner Production, 107, 95-104.

Emas, R. (2015). The Concept of Sustainable Development: Definition and Defining Principles. Florida: Florida International University. https:// sustainabledevelopment.un.org/content/documents/5839GSDR\%202015_SD_ concept_definiton_rev.pdf. Accessed 27 Nov 2016.

European Commission. (2015). Report on EU customs enforcement of intellectual property rights Results at the EU border 2015. Luxembourg: Publications Office of the European Union. https://ec.europa.eu/taxation_customs/sites/ taxation/files/2016_ipr_statistics.pdf. Accessed 27 Nov 2016.

Germani, M., Mandolini, M., Marconi, M., Marilungo, E., \& Papetti, A. (2015). A system to increase the sustainability and traceability of supply chains. Procedia CIRP, 29, 227-232.

Gilg, A., Barr, S., \& Ford, N. (2005). Green consumption or sustainable lifestyles? Identifying the sustainable consumer. Futures, 37(6), 481-504.

Global Recycle Standard. (2012). Global Recycle Standard, Version 2.1. http:// textileexchange.org/wpcontent/uploads/2016/06/Global-Recycle-Standard-V2. 1.pdf. Accessed 27 Nov 2016.

Gobbi, L., \& Massa, I. (2015). Supply chain management in textile sector: the case of the Italian T-fashion traceability system. International Journal of Environment and Health, 7(4), 359-370.

Goswami, S. (2014). Traceability to farm and factory, country of manufacturing, and apparel purchase scenario. Columbia: University of Missouri. https:// mospace.umsystem.edu/xmlui/handle/10355/44421. Accessed 27 Nov 2016.

Goworek, H. (2011). Social and environmental sustainability in the clothing industry: a case study of a fair trade retailer. Social Responsibility Journal, 7(1), 74-86.

Guercini, S., \& Runfola, A. (2009). The integration between marketing and purchasing in the traceability process. Industrial Marketing Management, 38(8), 883-891.

Harwood, R. R. (1990). A history of sustainable agriculture. In Sustainable agricultural systems (pp. 3-19).

Health, D. G., \& Consumers. (2013). Research support for an informal expert group on product traceability. European Commission. http://ec.europa.eu/ consumers/archive/safety/projects/docs/20131023_final-report_producttraceability-expert-group_en.pdf. Accessed 4 Dec 2016.

Henninger, C. E. (2015). Traceability the new eco-label in the slow-fashion industry?-Consumer perceptions and micro-organisations responses. Sustainability, 7(5), 6011-6032.

Hessel, C., Allegre, C., Maisseu, M., Charbit, F., \& Moulin, P. (2007). Guidelines and legislation for dye house effluents. Journal of Environmental Management, 83(2), 171-180.

Hethorn, J., \& Ulasewicz, C. (2008). Sustainable fashion: Why now (A conversation exploring issues, practices, and possibilities). Newyork: A \& C Black Publishers Ltd.

International organization for standardization. (2007). New ISO standard to facilitate traceability in food supply chain. ISO 22005:2007.

Islam, M. M., \& Khan, M. M. R. (2014). Environmental sustainability evaluation of apparel product: a case study on knitted T-shirt. Journal of Textiles, 2014, Article ID 643080. doi:10.1155/2014/643080.

Jacobs, M. (1995). Sustainable development-from broad rhetoric to local reality. In Conference Proceedings from Agenda 21 in Cheshire, 1 December 1994, Chesire County Council, Document No. 493.

Johansson, T., \& Månsson, H. (2013). Environmental Sustainability in the Fashion Industry (Master Thesis). Sweden: University of Gothenburg. https:/gupea.ub.gu. se/bitstream/2077/33404/1/gupea_2077_33404_1.pdf. Accessed 27 Nov 2016.

Juels, A. (2004). Minimalist cryptography for low-cost RFID tags. In C. Blundo, S. Cimato (Eds.) International Conference on Security in Communication Networks (pp. 149-164). Berlin, Heidelberg: Springer.

Khurana, K., \& Ricchetti, M. (2016). Two decades of sustainable supply chain management in the fashion business, an appraisal. Journal of Fashion Marketing and Management, 20(1), 89-104.

Kozlowski, A., Bardecki, M., \& Searcy, C. (2012). Environmental impacts in the fashion industry: a life-cycle and stakeholder framework. The Journal of Corporate Citizenship, 45, 17.

Kumar, V., Koehl, L., \& Zeng, X. (2016). A fully yarn integrated tag for tracking the international textile supply chain. Journal of Manufacturing Systems, 40, 76-86. 
Kumar, V., \& Ekwall, D. (2016). Macro-Scale Indicators Based Analysis of Textile Product Recalls in the EU. In Nofoma 2016, Turku, Finland. Presented at the NOFOMA.

Kutay, N., \& Tektüdekci, F. (2016). A new era for sustainable development: a comparison for sustainability indices. Journal of Accounting, Finance and Auditing Studies, 2(2), 70-95.

Kwok, S. K., \& Wu, K. K. (2009). RFID-based intra-supply chain in textile industry. Industrial Management \& Data Systems, 109(9), 1166-1178.

Lam, J. K., \& Postle, R. (2006). Textile and apparel supply chain management in Hong Kong. International Journal of clothing science and technology, 18(4), 265-277.

Martin, M. (2013). Creating sustainable apparel value chains: a primer on industry transformation, impact economy.

McDonough, W., \& Braungart, M. (2010). Cradle to cradle: remaking the way we make things. London: MacMillan.

Muthu, S. S. (2015). Environmental impacts of the use phase of the clothing life cycle. In S. S. Muthu (Ed.), Handbook of Life Cycle Assessment (LCA) of Textiles and Clothing, (pp. 93-102). Cambridge: Woodhead Publishing.

Muthu, S. S., Li, Y., Hu, J. Y., \& Mok, P. Y. (2011). Carbon footprint of shopping (grocery) bags in China, Hong Kong and India. Atmospheric Environment, 45(2), 469-475. doi:10.1016/j.atmosenv.2010.09.054.

Nagurney, A., \& Yu, M. (2012). Sustainable fashion supply chain management under oligopolistic competition and brand differentiation. International Journal of Production Economics, 135(2), 532-540.

Nayak, R., Singh, A., Padhye, R., \& Wang, L. (2015). RFID in textile and clothing manufacturing: technology and challenges. Fashion and Textiles, 2(1), 1-16.

Nicita, A., \& Razzaz, S. (2003). Who benefits and how much?: how gender affects welfare impacts of a booming textile industry. Policy Research Working Paper Series No. 3029. Washington, DC: World Bank.

Nimbalker, G., Mawson, J., \& Cremen, C. (2015). The truth behind the barcode: Australian fashion report. Baptist World Aid Australia. http://www.abc.net.au/ cm/lb/6398294/data/fashion-report-data.pdf. Accessed 4 Dec 2016.

Panorama, E. S. (2014). Employability and skills of higher education graduates: analytical highlight. Brighton: A Report by ICF GHK and Cedefop for the European Commission.

Pedersen, E. R. G., \& Andersen, K. R. (2015). Sustainability innovators and anchor draggers: a global expert study on sustainable fashion. Journal of Fashion Marketing and Management, 19(3), 315-327.

Phelan, H. (2011). Victoria's secret caught in child labor scandal. In Fashionista. http://fashionista.com/2011/12/victorias-secret-caught-in-child-labor-scandal. Accessed 23 Nov 2016.

Rapanui Clothing. (2016). Traceable clothing|Rapanui. https://rapanuiclothing. com/traceability-clothing/. Accessed 29 Nov 2016.

Regattieri, A., Gamberi, M., \& Manzini, R. (2007). Traceability of food products: general framework and experimental evidence. Journal of Food Engineering, 81(2), 347-356.

Ren, X. (2000). Development of environmental performance indicators for textile process and product. Journal of Cleaner Production, 8(6), 473-481.

Rose, M. (2014, 30 June). Inspections roil garment industry in Bangladesh. In Taipei Times (p. 9). Retrieved from http://www.taipeitimes.com/News/ editorials/archives/2014/06/30/2003593986. Accessed 27 Nov 2016.

Schröder, U. (2008). Challenges in the traceability of seafood. Journal für Verbraucherschutz und Lebensmittelsicherheit, 3(1), 45-48.

Seuring, S., \& Müller, M. (2008). From a literature review to a conceptual framework for sustainable supply chain management. Journal of Cleaner Production, 16(15), 1699-1710.

Shih, W. Y. C., \& Agrafiotis, K. (2015). Sustainability in Clothing Manufacturing and Competitiveness: Is It a New Mind-Set or a Paradox?. In S. S. Muthu (Ed.) Handbook of Sustainable Apparel Production (pp. 39-50). Florida: CRC Press.

Steinberger, J. K., Friot, D., Jolliet, O., \& Erkman, S. (2009). A spatially explicit life cycle inventory of the global textile chain. The International Journal of Life Cycle Assessment, 14(5), 443-455.

Strähle, J., Will, C., \& Freise, M. (2015). Communication of sustainability at European fashion online shops. International Journal of Economics, Commerce and Management, 3(7), 71-86.

Clothing Traceability (2017). Clothing Traceability. http://www.clothingtraceability. com/. Accessed 5 Mar 2017.

U.S. Department of Homeland Security. (2015). Intellectual Property Rights Seizure Statistics: Fiscal Year 2014. Washington, DC: U.S. Department of Homeland Security. https://www.cbp.gov/sites/default/files/documents/ 2014\%20IPR\%20Stats.pdf. Accessed 27 November 2016.
Ubilava, D., \& Foster, K. (2009). Quality certification vs. product traceability: consumer preferences for informational attributes of pork in Georgia. Food Policy, 34(3), 305-310

United Nations General Assembly (1987). Development and international economic co-operation: environment. Retrieved from http://undocs.org/A/ 42/427. Accessed 05 Mar 2017.

Veritas, B. (2010). Organic cotton frequently asked questions (FAQ). Bureau Veritas, http://www.bureauveritas.com/DanLLMuG/Bureau+VeritasOrganicCotton FAQ.pdf . Accessed 3 Oct 2016.

Walsh, D., \& Greenhouse, S. (2012, September 20). Inspectors certified pakistani factory as safe before disaster. The New York Times. http://www.nytimes. com/2012/09/20/world/asia/pakistan-factory-passed-inspection-before-fire. html. Accessed 27 Nov 2016.

Wigley, S. M., Sinha, P., Goworek, H., Fisher, T., Cooper, T., Woodward, S., \& Hiller A. (2012). The sustainable clothing market: an evaluation of potential strategies for UK retailers. International Journal of Retail \& Distribution Management, 40(12), 935-955.

World Commission on Environment and Development. (1987). Our common future. London: WCED-Oxford University Pres.

Yasin, S., Behary, N., Curti, M., \& Rovero, G. (2016). Global consumption of flame retardants and related environmental concerns: a study on possible mechanical recycling of flame retardant textiles. Fibers, 4(2), 16.

Yasin, S., Behary, N., Rovero, G., \& Kumar, V. (2016). Statistical analysis of use-phase energy consumption of textile products. The International Journal of Life Cycle Assessment, 21(12), 1776-1788

Zhang, T., \& Kraisintu, K. (2011). The role of traceability in sustainable supply chain management (Master Thesis). Retrieved from http://publications.lib.chalmers. se/records/fulltext/146242.pdf . Accessed 22 Nov 2016.

\section{Submit your manuscript to a SpringerOpen ${ }^{\circ}$ journal and benefit from:}

- Convenient online submission

- Rigorous peer review

- Immediate publication on acceptance

Open access: articles freely available online

- High visibility within the field

- Retaining the copyright to your article

Submit your next manuscript at $>$ springeropen.com 